\title{
A Century of Religious Freedom
}

\author{
Jesse H. Choper†
}

\section{TABLE OF CONTENTS}

Introduction

I. From Foundations to the Modern Era .........................................1712

A. The Free Exercise Clause ......................................................1713

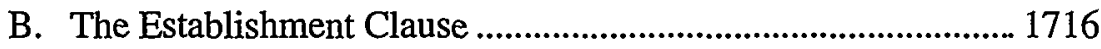

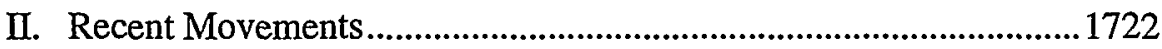

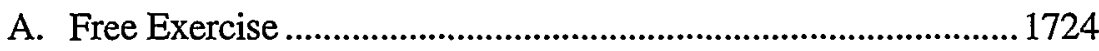

B. Separation of Church and State .............................................. 1729

1. Government Financial Assistance to Religious

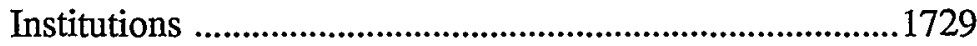

2. Government Acknowledgment of Religion .........................1735

3. Religion in Public Schools ................................................1738

III. An Uncertain Future........................................................................... 1741

Copyright $\odot 2000$ California Law Review, Inc. California Law Review, Incorporated (CLR) is a California nonprofit corporation. CLR and the authors are solely responsible for the content of their publications.

$\dagger \quad$ Earl Warren Professor of Public Law, School of Law, University of California, Berkeley (Boalt Hall). D. Hu. Litt., Wilkes University; L.L.B., University of Pennsylvania; B.S., Wilkes University. I would like to thank Sambhav N. Sankar, Boalt ' 00 , for his excellent assistance in the preparation of this Essay. 
[Vol. 88:1709 


\title{
A Century of Religious Freedom
}

\author{
Jesse H. Choper
}

The Religion Clauses of the First Amendment direct the separation of church and state and protect the free exercise of religion. Despite their position at the very beginning of the Bill of Rights, the Establishment and Free Exercise Clauses only attained their modern meaning within roughly the last half of the twentieth century. For much of that time, the Supreme Court's approach to the Free Exercise Clause was exemplified by the cases of Sherbert v. Verner and Wisconsin v. Yoder, while the Establishment Clause was implemented through the multipart test articulated in Lemon v. Kurtzman. A principled reading of these two areas of case law revealed a tension between accommodations required under the first and limitations on government action imposed by the second. In recent years, the Court has substantially revised its approach to nearly all facets of the Religion Clauses, but the resulting body of law is highly unstable. Nevertheless, some general themes are apparent, including the rise of a position of "neutrality" towards religion and a general approach that appears less separationist and more accommodating of mainstream religions.

\section{INTRODUCTION}

The initial clauses of the First Amendment of the Bill of Rights provide that "Congress shall make no law respecting an establishment of religion, or prohibiting the free exercise thereof." These brief words are the principal constitutional protections for religious liberty and the separation of church and state in a nation characterized by religious pluralism. As Justice Hugo L. Black reminded us, many of the first immigrants to this country fled lands in which they were compelled to support and attend state-sponsored churches, and where "[i]n efforts to force loyalty to whatever religious group happened to be ... in league with the government of a particular time and place, men and women had been fined, cast in jail, cruelly tortured, and killed." 2 When some of these very practices reappeared in their new country, ${ }^{3}$ many colonists were shocked and indignant. Their feelings culminated in the words of the First Amendment.

1. U.S. Const. amend. I.

2. Everson v. Board of Educ., 330 U.S. 1, 9 (1947).

3. For example, in Massachusetts, Quakers, Baptists, and other religious minorities suffered harsh treatment and were taxed for the benefit of the established Congregational Church. See LEONARD 
Of course, while "[t]he sweep of the absolute prohibitions in the Religion Clauses may have been calculated[,] . . . the purpose was to state an objective, not to write a statute."4 Even if the Framers' intent were clear and unambiguous - and it was not ${ }^{5}$ - they could not have imagined the remarkable religious heterogeneity that is today a commonplace feature of American life, or the demands that its "free exercise" might place upon the fabric of society. Public education, the source of so many modern disputes over cliurcli and state separation, was virtually unknown to them, as were unemployment insurance, antidiscrimination laws, and many of the other programs that have proven problematic over the years. Thus, our nation's courts, and chiefly the United States Supreme Court, shoulder the task of implementing the visions of Thomas Jefferson, James Madison, and Roger Williams through interpreting the text of the First Amendment. At the end of this second full century of our constitutional heritage, it is appropriate to critically reflect on the soundness and consistency of the Supreme Court's constructions of the religion clauses over the past century, as well as to consider the doctrinal direction in which the Court might go during the next one.

\section{I}

\section{From Foundations to the Modern ERA}

Surprising as it may seem, the last hundred years tell nearly the entire story of the federal judiciary's role in America's experiments with the Religion Clauses. First of all, before the middle of this century, these provisions of the Bill of Rights applied only to the federal government; ${ }^{6}$ since the states enacted most legislation, and Congress was quite inactive in regulating domestic affairs, there simply was not much occasion for the Supreme Court to interpret the Free Exercise and Establishment Clauses. Where they were in issue, the Court afforded them a relatively restricted ineaning. ${ }^{7}$ It was not until the 1940s that the Court gradually began to give the concepts of religious freedom and separation of church and state the

W. Levy, The Establishment Clause: Religion and the First Amendment 15-20 (1986). In 1776, section XXXIII of the Maryland "Declaration of Rights" stated that "all persons, professing the Christian religion, are equally entitled to protection in their religious liberty," and not until 1826 were Jews permitted to hold public office. 3 The Federal and State Constitutions, Colonial Charters, AND OTher Organic Laws 1689 (Francis Newton Thorpe ed., 1909). Section XXXVIII of the South Carolina Constitution of 1778 stated that "[t]he Christian Protestant religion shall be deemed... the established religion of this State." 6 The Federal and State Constitutions, Colonial Charters, and Other Organic Laws 3255.

4. Walz v. Tax Comm'n, 397 U.S. 664, 668 (1970).

5. See Jesse H. Choper, The Religion Clauses of the First Amendment: Reconciling the Conflict, 41 U. PiTT. L. Rev. 673, 676 (1980).

6. The Supreme Court extended the mandate of the Free Exercise and Establishment Clauses to the states in Cantwell v. Connecticut, 310 U.S. 296, 303 (1940), and Everson v. Board of Education, 330 U.S. 1, 15 (1947), respectively.

7. See infra text accompanying notes $37-40$. 
more vigorous meaning that we generally associate with then today. As Section III will show, however, the modern Court has modified the separationist and protective stance it took in the 1960s and 1970s, and its most recent doctrinal moves indicate that the future path of the law may be unclear.

\section{A. The Free Exercise Clause}

The bedrock test of a government's commitment to protecting the free exercise of religion arises when general government regulations, enacted for secular purposes, conflict with an individual's religious beliefs. ${ }^{8}$ Before this century, the Supreme Court's posture in these situations was decidedly unsynipathetic to religious freedoms. In 1879, Reynolds $v$. United States ${ }^{9}$ refused to invalidate the polygamy conviction of a Mormon on free exercise grounds, ${ }^{10}$ drawing a sharp distinction between an individual's "freedoni to believe" and his "freedom to act": "Laws are niade for the governinent of actions, and while they cannot interfere with mere religious belief and opinions, they niay with practices."11 To hold otherwise, the Court believed, "would be to make the professed doctrines of religious belief superior to the law of the land, and in effect to permit every citizen to become a law unto himself." 12 Though it was articulated in the nineteenth century, the belief/action distinction established in Reynolds remained vital well into this century and greatly limited the reach of the Free Exercise Clause while it held sway. ${ }^{13}$

Even when the Court first invalidated a government action on free exercise grounds in its 1940 decision in Cantwell $v$. Connecticut, ${ }^{14}$ it retained the distinction between the freedon to believe and the freedom to act, although it added that, in the latter instance, the government's "power to regulate must be so exercised as not, in attaining a permissible end, unduly to infringe the protected freedom." ${ }^{15}$ Cantwell was unquestionably a landniark in the law of free exercise ${ }^{16}$ but it rested largely on free speech principles, and so had linited inipact in those cases in which only free

8. See Jesse H. Choper, The Rise and Decline of the Constitutional Protection of Religious Liberty, 70 NeB. L. Rev. 651, 653 (1991).

9. 98 U.S. 145 (1879).

10. Mormon doctrine required male members of the church to practice polygamy where circumstances permitted; the penalty for failure would be "damnation in the life to come." Id. at 161 .

11. Id. at 166 .

12. Id. at 167 .

13. As we shall see, this approach has gained new life in the important recent Free Exercise decision of Employment Division, Department of Human Resources v. Smith, 494 U.S. 872 (1990), discussed infra in text accompanying notes 106-15.

14. 310 U.S. $296(1940)$.

15. Id. at 304 .

16. Cantwell was a landmark if for no other reason than its application of tbe Free Exercise Clause of the First Amendment to the states under the Fourteenth Amendment. See id. at 303. 
exercise was at stake. Two opinions the Court issued a few years later are particularly instructive: In West Virginia State Board of Education $v$. Barnette, ${ }^{17}$ Jehovah's Witnesses refused to allow their children to salute the United States flag while repeating the Pledge of Allegiance because doing so would violate their religious bar on the worship of graven images. The Court explicitly avoided the issue of whether the Free Exercise Clause protected this behavior ${ }^{18}$ and instead invalidated the regulation on free speech grounds. ${ }^{19}$ And when a free exercise clain was asserted without a concurrent free speech claim in Prince $v$. Massachusetts, ${ }^{20}$ the Court upheld the government regulation in question, reiterating the rationale of Reynolds and Cantwell that government nuay ordinarily regulate religious conduct to advance the welfare of society. ${ }^{21}$ That approach basically remained the norm until 1963: Although the Court had said that the Free Exercise Clause may require a religious exemption from a general law regulating conduct when the legislation conflicts with religious precepts, the Court's decisions had never granted one. ${ }^{22}$

In that year, however, the Court, for the first time, invalidated state regulation of religious action on free exercise grounds alone. Adell Sherbert, a Seventh Day Adventist, had refused to work on Saturday when her employer moved to a six-day work week. When she filed for unemploynient benefits, she was barred by a South Carolina statute that disqualified unemployed persons who failed to accept "suitable work." Justice William J. Brennan, Jr.'s views on the subject had caused him to dissent a few years earlier from the Court's refusal to require an exemption fronı a Sunday Closing Law for orthodox Jewish merchants whose religious precepts denianded that they close their businesses on Saturday. ${ }^{23} \mathrm{He}$ now wrote for the Court in Sherbert $v$. Verner. ${ }^{24}$ Drawing on recent free speech cases, he first recognized that conditioning an applicant's benefits "upon ... [her] willingness to violate a cardinal principle of her religious

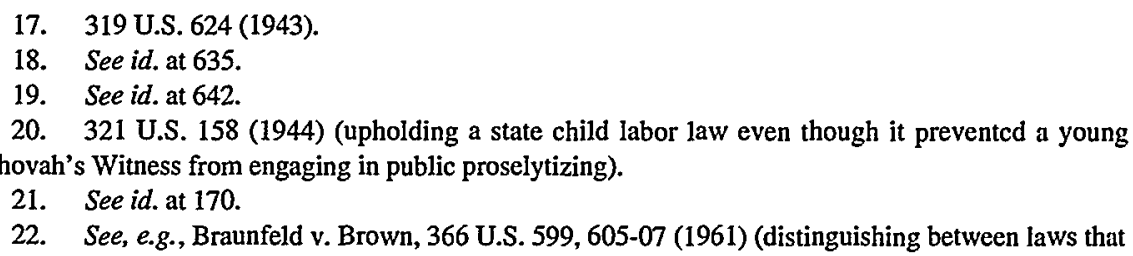
"make a religious practiee itself unlawful" and those that "impose[ ] only an indirect burden on the exercise of religion" so as only "to make the practice of their religious beliefs more expensive," and explaining that "if the State regulates conduct by enacting a general law within its power, the purpose and effect of which is to advance the State's secular goals, the statute is valid despite its indirect burden on religious observance unless the State may accomplish its purpose by means which do not impose such a burden") (citation omitted).

23. See id. at 613 (Brennan, J., dissenting) ("[T]he laws do not say that appellants must work on Saturday. But their effect ... is that no one may at one and the same time be an Orthodox Jew and compete effectively with his Sunday-observing fellow tradesmen.").

24. 374 U.S. 398 (1963). 
faith effectively penalizes the free exercise of her constitutional liberties."25 Next, he transformed Cantwell's pregnant dictum into a new doctrinal test: However indirect the effects of a state law might be, "any incidental burden on the free exercise of ... religion [must] be justified by a 'compelling state interest."'

A decade later, the Court used this "strict scrutiny" test to establish the high water mark for religious protection under the Free Exercise Clause. In Wisconsin v. Yoder, ${ }^{27}$ the Court sided with Amish parents who refused to comply with the state's compulsory school attendance statute after their children had completed the eighth grade. In an effectively unanimous opinion, the Justices recognized that enforcing the statute would "gravely endanger if not destroy the free exercise of respondents' religious beliefs." ${ }^{28}$ Moreover, it fully rejected the outmoded belief/action distinction, stating that at least in the case of the Amish, "belief and action cannot be neatly confined in logic-tight coinpartments."29 But most importantly, the opinion demonstrated how strongly protective of religious liberty the Sherbert approach could be. When subjected to "strict scrutiny," Wisconsin's interest in preparing students for participation in modern life could not stand against the success and agrarian self-sufficiency of the Amish people. Religious freedom would be secured against undeniably neutral legislation that served highly laudable goals. Quoting Sherbert, the Yoder Court indicated that to be "coinpelling," the interest a state regulation must address would have to involve "some substantial threat to public safety, peace, or order." ${ }^{\text {30 }}$

As for my own views on the subject, I agree that the First Amendment is not simply a prohibition against regulations that single out religious behavior for sanction or burden. Bare neutrality towards religion would prohibit all religious exemptions from generally applicable laws no matter how insubstantial the competing state interest might be. I believe that such a doctrine inadequately reflects the positive value that the First Amendment assigns to religion. In my judgment, our Constitution calls for religion to be treated specially; that means more than that religion must be treated equally. Thus, under the Free Exercise Clause, I believe that religion must sometimes be afforded special privilege-that is, a "preference."

25. Id. at 406 (citing Speiser v. Randall, 357 U.S. 513 (1958)).

26. Id. at 403 (quoting NAACP v. Button, 371 U.S. 415,438 (1963)).

27. 406 U.S. 205 (1972).

28. Id. at 219. The decision was only effectively unanimous because Justice Douglas believed that the children's wishes must be accounted for.

29. Id. at 220 .

30. Id. at 230 (quoting Sherbert v. Verner, 374 U.S. 398, $402-03$ (1963)).

31. See Jesse H. Choper, Securing Religious Liberty: Principles for Judicial INTERPRETATION OF THE RELIGION CLAUSES 54-57 (1995). 
At the same time, any religious exemption must pass muster under the Establishment Clause. At the time of Sherbert and Yoder, the Court read this provision to forbid any government action whose purpose or primary effect was to aid religion-a formulation that would seem to flatly prohibit the Court's own requirements in those two cases. To avoid results that the Court found insufficiently protective of religion, both decisions appear to have subordinated the values of the Establishment Clause in favor of free exercise, an approach that seems to lack any principled rationale or limitation. As I have suggested elsewhere, a better approach would be to forbid all laws whose purpose is to aid religion, including religious exemptions from general government regulations, if such laws tend to coerce, compromise, or influence religious beliefs. ${ }^{32}$ Under my approach, Mrs. Sherbert would not have received a judge-made exemption from South Carolina's employment laws: That exemption was given solely for religious purposes and coerces other citizens to subsidize her religious activity. ${ }^{33}$ Yoder, on the other hand, would not be problematic. Although it too creates an exception intended for the benefit of religion, the Court's decision would neither coerce citizens to join or desert the Amish faith, nor would it support the Amish with tax revenues (apart from any issue of the free exercise rights of Amish children, which the Court ruled was not before it).

The Court has noted the conflict between its Establishment Clause and Free Exercise jurisprudence, ${ }^{34}$ but has not successfully resolved the problems the tension creates. ${ }^{35}$ Instead, as Section III will show, it has simply stepped back from the proreligion stance of Sherbert and Yoder, with its special accommodation for religious views.

\section{B. The Establishment Clause}

Like the Free Exercise Clause, the Establishment Clause lay substantially dormant before Everson v. Board of Education ${ }^{36}$ extended its mandate to the states. Until then, only two Supreme Court decisions had given the clause any significant consideration. One hundred years ago, Bradfield v. Roberts ${ }^{37}$ upheld federal appropriations to a Roman Catholic hospital for care of indigent patients. ${ }^{38}$ And in 1908, Quick Bear v. Leupp ${ }^{39}$ sustained

32. See Choper, supra note 5, at 691 .

33. See CHOPER, supra note 31 , at 120-23. Note that my approach would uphold a generally applicable exemption allowing any citizen to refuse to work on one particular day a week.

34. See, e.g., Walz v. Tax Comm'n, 397 U.S. 664, 668-69 (1970) ("The Court has struggled to find a neutral course between the two Religion Clauses, both of which are cast in absolute terms, and either of which, if expanded to a logical extreme, would tend to clash with the other.").

35. See Corporation of the Presiding Bishop of the Church of Jesus Christ of Latter-Day Saints v. Amos, 483 U.S. 327 (1987) (discussed infra at text accompanying note 117).

36. 330 U.S. 1,8 (1947).

37. 175 U.S. 291 (1899).

38. See id. at $295,299-300$.

39. 210 U.S. 50 (1908). 
federal disbursement of funds held in trust for the Sioux Indians to Catholic schools designated by the Sioux for payment of tuition. ${ }^{40}$

Everson provided the Court's first serious attempt to explain the principle of nonestablishment. In upholding a township's practice of reimbursing parents for the cost of busing their children to and from schools, including parochial schools, the Court said that the Establishment Clause meant "at least" that:

Neither a state nor the Federal government can set up a church. Neither can pass laws which aid one religion, aid all religions, or prefer one religion over another. Neither can force nor influence a person to go to or to remain away from a church against his will or force him to profess a belief or disbelief in any religion. No person can be punished for entertaining or professing religious beliefs or disbeliefs, for church attendance or nonattendance. No tax in any amount, large or small, can be levied to support any religious activities or institutions, whatever they may be called, or whatever form they may adopt to teach or practice religion. Neither a state nor the Federal Government can, openly or secretly, participate in the affairs of any religious organization or groups and vice versa. ${ }^{41}$

One can scarcely imagine a stronger "wall of separation"42 between church and state than the one envisioned in this passage. But despite its categorical prescriptions, and the support that it found among the Justices of the Everson Court, ${ }^{43}$ its precise meaning is not readily discernible from its text: What, for example, constitutes impermissible "aid" to or "support" of religion?

Everson involved one of the most persistent issues under the Establishment Clause-namely, what financial aid government may give to religious institutions. For some time after that case, however, the Court's primary emphasis was upon the propriety of religion in the public schools. In particular, two important cases concerned "released time," the practice of voluntary religious instruction by privately employed religious teachers during normal school hours while regular classes are suspended. In McCollum v. Board of Education, ${ }^{44}$ the Court struck down an Illinois released time program that instructed students on the public school premises, ${ }^{45}$ while Zorach $v$. Clauson ${ }^{46}$ upheld a similar program that used neither

40. See id. at 81-82.

41. Everson, 330 U.S. at 15-16.

42. Id. at 16 (citing Reynolds v. United States, 98 U.S. 145, 164 (1879)).

43. Although Justices Robert Jackson, Wiley Rutledge, Felix Frankfurter, and Harold Burton dissented from the majority opinion in Everson, they did so on the grounds that the result was not sufficiently separationist. See id. at 63 (Rutledge, J., dissenting).

44. 333 U.S. 203 (1948).

45. See id. at 211-12.

46. 343 U.S. 306 (1952). 
public funds nor public facilities. ${ }^{47} \mathrm{McCollum}$, Zorach, and other postEverson cases failed to articulate coherent doctrinal principles for interpreting the Establishment Clause, ${ }^{48}$ but more importantly, they show how the Court has hesitated to enforce the starkly separationist vision of Everson-even relatively soon after it was articulated.

McGowan v. Maryland $d^{49}$ was the first of several cases that laid the framework for the Establishment Clause jurisprudence that governed from the early 1970 s to the mid-1980s. The case involved Maryland's Sunday Closing Law, which prohibited the sale of most merchandise on Sundays. Although the statute clearly comported with and favored the Christian faiths, Maryland claimed that its purpose was secular: "[T] set one day apart from all others as a day of rest, repose, recreation, and tranquillity." The Court agreed, and laid down the first part of what would become the famous (and controversial) Lemon test: For a law to survive Establishment Clause review, it must have a secular purpose. ${ }^{51}$ Abington School District $v$. $S c h e m p p^{52}$ clarified the doctrine further. In evaluating the practice of daily classroom Bible readings and recitation of the Lord's Prayer in public schools, the Court asked, "what are the purpose and primary effect of the enactment?"53 After Abington, to survive review under the First Amendment, laws had to have "a secular legislative purpose and a primary effect that neither advances nor inhibits religion." 54 This purpose/effect formulation was later divided to become the first two prongs of the Lemon test.

After several cases involving religious exercises in public schools, the Court returned to the issue it had considered in Everson-namely, aid to church-related institutions, particularly parochial schools. In Board of Education v. Allen, ${ }^{55}$ and especially in Walz v. Tax Commission, ${ }^{56}$ it developed what would become the third, or "entanglement" prong of the Lemon

47. See id. at 308,315 . It was in Zorach that the Court issued one of its most controversial, but now antiquated, pronouncements in regard to the Establishment Clause:

We are a religious people whose institutions presuppose a Supreme Being. We guarantee the freedom to worship as one chooses. We make room for as wide a variety of beliefs and creeds as the spiritual needs of man deem necessary.... When the state encourages religious instruction or cooperates with religious authorities by adjusting the schedule of public events to sectarian needs, it follows the best of our traditions.

Id. at 313-14.

48. See also Engel v. Vitale, 370 U.S. 421, 425 (1962) (invalidating the practice of reciting a state-composed prayer in public school, even though students could remain silent or leave the room, because it "is no part of the business of government to compose official prayers").

49. 366 U.S. 420 (1961).

50. Id. at 450.

51. See id. at 444-45.

52. 374 U.S. 203 (1963).

53. Id. at 222 .

54. Id.

55. 392 U.S. 236 (1968).

56. 397 U.S. 664 (1970). 
test. After the Court approved of a state's textbook lending program that included church-related schools in Allen, it refused in Walz to strike down a state tax exemption for "real or personal property used exclusively for religious, educational, or charitable purposes." 57 The Court found that the exemption in Walz had the nonreligious purpose of avoiding inhibitions on the activities of a broad class of community institutions that "foster its "moral or mental improvement," 58 but cautioned: "We must also be sure that the end result-the effect-is not an excessive government entanglement with religion.... [The question is] whether it is a continuing one calling for official and continuing surveillance leading to an impermissible degree of entanglement." ${ }^{59}$ The Court noted that an exemption might occasion less entanglement than nonexemption: Taxation would have involved "valuation of church property, tax liens, tax foreclosures, and the direct confrontations and conflicts that follow in the train of those legal processes." 60

Thus, the Court's three-part Establishment Clause test, named after its reasoning in Lemon $v$. Kurtzman, ${ }^{61}$ was fairly well developed by the time of that decision. When Pennsylvania and Rhode Island attempted to subsidize the salaries of nonpublic school teachers, including those in parochial schools, for their secular teaching, the Court rejected the programs on First Amendment grounds. The Court first found (as it nearly always did in later cases) that the legislation in question had a secular purpose; in fact, Pennsylvania and Rhode Island had instituted significant restrictions to ensure that tax dollars were not spent for religious purposes. But paradoxically, these precautions proved to be the undoing of the very programs they were supposed to protect. Noting that the states would have to engage in a "comprehensive, discriminating, and continuing state surveillance"62 to prevent misuse of tax funds for religious purposes, the Court rejected the programs as impermissibly entangling, and "pregnant with dangers of excessive government direction of church schools and hence of churches." ${ }^{163}$ Furthermore, both laws risked another sort of entanglement, this one associated with their "divisive political potential" ${ }^{\prime 64}$ along religious lines, given the likelihood that annual appropriations demands would increase.

57. Id. at 666-67 (quoting N.Y. CoNsT. art. 16, $§ 1$ ).

58. Id. at 672 .

59. Id. at $674-75$.

60. Id. at 674 .

61. 403 U.S. 602 (1971). The Lemon test was phrased as follows: "First, the statute must have a secular legislative purpose; second, its principal or primary effect must be one that neither advances nor inhibits religion; finally, the statute must not foster 'an excessive government entanglement with religion." Id. at 612-13 (citations omitted).

62. Id. at 619 .

63. Id. at 620 .

64. Id. at 622 . 
Along with a number of others, ${ }^{65}$ I criticized both the underpinnings and results of the three-part test. ${ }^{66}$ First, the Court's emphasis on nonsecular purpose posed two serious difficulties. Although the Court's Establishment Clause opinions preached the virtues of a "wholesome" government neutrality towards religion, its Free Exercise rulings showed that in some circumstances neutrality is not constitutionally mandated. In fact, those cases sometimes held that the First Amendment requires government to act with a nonsecular purpose in order to permit the unburdened exercise of religion. Moreover, the Court was never fully committed to its stated opposition to government action for religious purposes even in the area of religion in public schools. For example, it specifically reaffirmed Zorach's approval of an off-premises released time program, even though its purpose-the facilitation of religious instruction-was clearly nonsecular.

I also found the "entanglement" prong significantly flawed, believing that nonentanglement is not a value ${ }^{67}$ the judiciary can or should secure through the Establishment Clause. Perhaps the major fear of those concerned with entanglement is that government regulation will impair the ability of religious groups to pursue their mission. However, since 1925 the Court has allowed states to regulate religious institutions; ${ }^{68}$ the curricula of parochial schools is only one example. The propriety of such regulation should not be significantly affected by the presence or absence of concurrent financial aid. Government scrutiny of religious activities is indeed an extremely sensitive task, but the Constitution explicitly demands that religion be given such treatment under certain circumstances, as when, for example, the government funds secular activities by religious institutions. As for the argument that entanglement is dangerous because it provokes "political strife along religious lines," one need only recognize that political strife often occurs along religious lines, even on what many regard as secular issues such as abortion, prostitution, gambling, obscenity, and so on. The mere fact that opponents and proponents of a law line up according to their religious beliefs cannot make the law itself unconstitutional. ${ }^{69}$

65. See, e.g., Donald A. Giannella, Lemon and Tilton: The Bitter and Sweet of Church-State Entanglement, 1971 SuP. CT. REv. 147; Douglas Laycock, Towards a General Theory of the Religion Clauses: The Case of Church Labor Relations and the Right to Church Autonomy, 81 Colum. L. Rev. 1373 (1981).

66. See Choper, supra note 5, at 678-86.

67. This value was originally championed in an influential article by Paul Freund, Public Aid to Parochial Schools, 82 HARv. L. REv. 1680 (1969), discussed by Justice John M. Harlan in his separate opinion in Walz v. Tax Comm'n, 397 U.S. 664, 695 (1970).

68. See Pierce v. Society of Sisters, 268 U.S. 510 (1925) (holding that, although states may not require that all children be educated in public schools, they may prescribe reasonable educational standards).

69. In addition, avoiding conflict in one way may provoke it in another. For example, if religious parents cannot obtain state support of parochial schools, they may oppose increased funding of public schools as an alternative. 
At the doctrinal level, the Lemon test produced great incoherence-a situation that I have described as "a conceptual disaster area."70 The subtlety of the factual distinctions the Court drew at times were beyond the grasp of most observers. Therapeutic and diagnostic health services provided by public employees to parochial school students were invalid when offered in the school, ${ }^{71}$ but not when offered in a mobile unit adjacent to the school $;^{72}$ Allen allowed the states to lend textbooks to parochial school pupils because they can be screened for religious content, ${ }^{73}$ but other seemingly "self-policing" items like tape recorders, films, movie projectors, laboratory equipment, and maps were prohibited. ${ }^{74}$ The list goes on, ${ }^{75}$ but the point is clear: The Court was never willing to truly abide by the Lemon test, both because the test lacked any founding principle, and because it produced results that were simply too separationist for a majority of the Court to endorse. In this sense, the history of the Lemon test recalls that of Sherbert and Yoder. All set out strict standards that were quite influential in the lower courts, but the Supreme Court itself often declined to heed its own words.

As suggested earlier, my own view is that specific church-state problems should be resolved by recourse to a broad principle that accounts for the major function of the Establishment Clause (as well as the Free Exercise Clause)-protection of religious liberty. ${ }^{76}$ Threats to this liberty may arise in a number of ways, by coercing religious beliefs either directly or indirectly, or by strongly influencing religious choice. And an important illustration of coercion is government-compelled financial support, that is, use of tax-raised funds for religious activities. ${ }^{77}$ The Court should forbid

70. Jesse H. Choper, Federal Constitutional Issues, in School CHOICE AND Social Controversy: Politics, Policy, AND LAw 235, 237 (Stephen D. Sugarman and Frank R. Kemerer eds., 1999).

71. See Meek v. Pittenger, 421 U.S. 349, 367, $371-72$ (1975).

72. See Wolman v. Walter, 433 U.S. 229, 247 (1977).

73. See Board of Educ. v. Allen, 392 U.S. 236, 244-45 (1968)

74. See Meek, 421 U.S. at 365.

75. Compare Committee for Pub. Educ. v. Nyquist, 413 U.S. 756 (1973) (holding that government reimbursement to parents whose children attended nonpublic and predominantly parochial schools of a percentage of the tuition paid violated the Establishment Clause because, although the purpose was secular, the effect was to advance religion in the schools since there was no limitation on the purpose for which the funds might be used), with Mueller v. Allen, 463 U.S. 388 (1983) (upholding the constitutionality of a state income tax deduction to all taxpayers for expenses of tuition, transportation, textbooks, instructional materials, and other school supplies in publie and nonpublic schools since the purpose and primary effect of the facially neutral law were secular, despite the fact that the great bulk of deductions could be taken only by parents of children in parochial schools). In 1980, even the Court forthrightly conceded that its approach under the Lemon test "sacrifices clarity and predictability for flexibility." Committee for Pub. Educ. v. Regan, 444 U.S. 646, 662 (1980).

76. See CHOPER, supra note 31 , at 97 (concluding that even "government programs that deliberately favor religious interests" do not violate the Establishment Clause unless they pose a "significant threat to religious liberty or are discriminatory").

77. See id. at 117-19. 
government action only when its purpose is religious and it is likely to impair religious freedom by coercing, compromising, or influencing religious beliefs. ${ }^{78}$

\section{II}

\section{RECENT MOVEMENTS}

Given the checkered history of the Sherbert-Yoder and Lemon tests, it is not surprising that, over time, the Court has moved away from its contradictory separationist and proreligion stances. In the past decade, the Court has made major changes in its approach to every important aspect of the Religion Clauses, and additional moves may well occur in the near future. In recent cases touching on the primary area of constitutional adjudication under the Free Exercise Clause (religious exemptions from neutral regulations), and in each of the three major areas of constitutional adjudication under the Establishment Clause (government aid to religious institutions, government acknowledgment of religion, and religion in public schools), one may discern four general themes.

First, the Supreme Court has moved away from affording religion "special" treatment (either by forbidding it certain benefits or granting it exemptions from certain burdens) and has moved toward a position of neutrality (or equality) on church-state issues, attempting to steer a more nonpartisan course between sacred and secular institutions and between religious and nonreligious individuals. ${ }^{79}$ Although "neutrality" is an important value of the Religion Clauses, in my view unqualified adherence to this goal would allow-indeed, demand-state advancement and support of religion well beyond what should be encompassed within our tradition of church-state separation, and yet would also afford insufficient protection of religious liberty by permitting application of neutral government regulations to burden religious interests. ${ }^{80}$ As discussed earlier, ${ }^{81}$ my own view is that the Constitution demands special treatment for religion-that is, more than mere equality. Thus, I believe that under the Free

78. Although the Court appeared to reject this approach in an early opinion, see Engel v. Vitale, 370 U.S. 421, 430-31 (1962) (stating that the purposes of the Establishment Clause go "much further" than merely avoiding coercion), it nevertheless often carefully analyzed the elements of coercion and influence in programs it has considered. For example, in Engel, the Court pointed out "the indirect coercive pressure upon religious minorities to conform to the prevailing officially approved religion," $i d$. at 431 , and in upholding the released time program in Zorach v. Clauson, 343 U.S. 306 (1952), it emphasized the lack of "coercion to get public school students into religious classrooms." Id. at 311. See also Widmar v. Vincent, 454 U.S. 263 (1981), where the Court noted the differing effects of religion in a classroom depending upon the age of the student: "University students are... less impressionable than younger students and should be able to appreciate that the University's policy is one of neutrality toward religion." Id. at 274 n.14.

79. See infra text accompanying notes 108-12, 130-32, 136, 141, \& 190.

80. For examples, see CHOPER, supra note 31, at 19-24.

81. See supra text accompanying note 31 . 
Exercise Clause, religion must sometimes be afforded "preferred" status, and that under the Establishment Clause, religion must at times be "disfavored" through special limits. ${ }^{82}$

Second, the Court has implicitly abandoned the Lemon test ${ }^{33}$ for the validity of enactments under the Establishment Clause, and has in its stead adopted an approach championed by Justice Sandra Day O'Connor-the "endorsement" test. Initially articulated in the mid-1980s, this test would find an Establishment Clause violation when government "endorses religion," which occurs whenever a reasonable observer would conclude that official activity "sends a message to nonadherents that they are outsiders, not full members of the political community, and an accompanying message to adherents that they are insiders, favored members of the political community." 84

The standard that had competed for about a half-dozen years to replace the Lemon test was Justice Anthony Kennedy's "coercion" approach. The choice of the word "coercion" as a title for this test is probably unfortunate because Justice Kennedy defined the term much more broadly than is usually done, allowing that the coercion required for an Establishment Clause violation may take a variety of "more or Iess subtle" forms, including "taxation to supply the substantial benefits that would sustain a state-established faith, direct compulsion to observance, or governmental exhortation to religiosity that amounts in fact to proselytizing." "85 Justice Kennedy's approach is the closest any Justice on the Court has come to my own Establishment Clause principles. ${ }^{86}$

Of the present members of the Court, Chief Justice William $\mathrm{H}$. Rehnquist and Justice Antonin Scalia joined in Justice Kennedy's dissenting opinion in County of Allegheny v. American Civil Liberties Union, ${ }^{87}$ which contains the fullest exposition of the "coercion" test, ${ }^{88}$ and Justice Clarence Thomas has since subscribed to its core principle. ${ }^{89}$ These same

82. See generally CHOPER, supra note 31, at 21-24.

83. The Lemon test is discussed supra in text accompanying notes 61-78. The Court had its best chance to formally disapprove of the Lemon test in Lamb's Chapel v. Center Moriches Union Free School District, 508 U.S. 384 (1993), but failed to do so. See Jesse H. Choper, Benchmarks, 79 A.B.A. J. 78 (Nov. 1993). Justice Scalia, remarking on the test's resilience, likened it to "some ghoul in a late-night horror movie that repeatedly sits up in its grave and shuffles abroad, after being repeatedly killed and buried." Lamb's Chapel, 508 U.S. at 398 (Scalia, J., concurring).

84. Lynch v. Donnelly, 465 U.S. 668, 688 (1984) (O'Connor, J., concurring). For more extensive elaboration and application of the endorsement test, see Justice O'Connor's concurring opinions in Capitol Square Review \& Advisory Board. v. Pinette, 515 U.S. 753, 772-95 (1995); County of Allegheny v. ACLU, 492 U.S. 573, 623-37 (1989); and Wallace v. Jaffree, 472 U.S. 38, 67-79 (1985).

85. Allegheny, 492 U.S. at 659-60 (Kennedy, J., concurring in part and dissenting in part).

86. See supra text accompanying notes 32-33.

87. 492 U.S. 573 (1989).

88. See also Board of Educ. v. Mergens, 496 U.S. 226, 258-62 (1990) (Kennedy, J., concurring).

89. See Lee v. Weisman, 505 U.S. 577, 640 (1992) (Scalia, J., dissenting, joined, inter alia, by Thomas, J.). For discussion of how Justice Kennedy's "coercion" approach failed to be installed as the 
four justices have most recently emphasized the neutrality approach, not only describing it as "a significant factor in upholding government programs in the face of Establishment Clause attack," ${ }^{\circ 0}$ but also flatly declaring that "it is no violation for government to enact neutral policies that happen to benefit religion."

Third, the current Court is less separationist than in the past. This has resulted in its becoming more accommodationist toward the "major" or "mainstream" religions, namely the dominant Judeo-Christian faiths. The fourth theme, which is in a sense the opposite side of the third theme's coin, is that the Court has become substantially less protective of "smaller" or "nonconforming" religious groups. Both of these final themes may be seen as products of greater judicial restraint on the part of the present Supreme Court in respect to individual rights-an increased willingness by the prevailing majority to defer to the elected branches of government, and a greater reluctance to reject government action in favor of personal liberty.

Although I am generally supportive of the trend toward greater accommodation manifested in the third theme, at least in the absence of any meaningful threat to religious liberty, I disagree with the Court's shrunken protection for smaller religions found in the fourth. In my view, the major role of the Court and the institution of judicial review is to provide protection for those without the numbers and influence to ensure significant protection through the political process, especially when constitutional rights are involved. ${ }^{92}$ Thus, I believe that the Court should actively review government actions that pose a significant threat to religious liberty.

\section{A. Free Exercise}

Although the robust "strict scrutiny" test developed in Sherbert and Yoder greatly influenced lower court decisions, the Supreme Court itself has been markedly less hospitable to subsequent free exercise claims. Virtually all of its later decisions, while often invoking strict scrutiny, have ruled in favor of government regulations. Some of these decisions are supportable, as they find "compelling" state interests in arenas whose importance the Court has often recognized. ${ }^{93}$ Others upholding regulations on

operative standard despite its support at one time by a majority of the Court, see Choper, supra note 83, at 80 .

90. Rosenberger v. Rector \& Visitors of Univ. of Va., 515. U.S. 819, 839 (1995) (emphasis added).

91. Capitol Square Review \& Advisory Bd. v. Pinette, 515 U.S. 753, 764 (1995).

92. See generally Jesse H. Choper, Judicial Review and the National Political Process: A Functional Reconsideration of the Role of the SUPREME Court (1980).

93. See Bob Jones Univ. v. United States, 461 U.S. 574 (1983) (eradicating racial discrimination in education); Gillette v. United States, 401 U.S. 437 (1971) (finding effective administration of the 
citizens who hold dimimished rights to free exercise by virtue of circumstance employed a standard of review more deferential to government authority than strict scrutiny. ${ }^{94}$ But a number of rulings are harder to justify, and represent the growing influence of the first theme (that is, neutrality) on the Court's jurisprudence.

In United States v. Lee, ${ }^{95}$ an Amish employer refused to pay Social Security taxes on his Amish employees' wages, based on his faith's belief that it is sinful not to provide for financially dependent members of the community. ${ }^{96}$ Instead of seriously applying the strict scrutiny test as it had done in Yoder, a unanimous Court simply noted that the government had an "overriding" interest in every citizen's adherence to a comprehensive social security system. ${ }^{97}$ In essence, the Court felt that accommodating the Amish belief would be too administratively complex and actuarially dangerous. It is quite difficult to reconcile this holding with Yoder. In both cases, the Amish chose to "opt out" of both the burdens and the benefits of a government program on religious grounds. In fact, Congress had already granted a statutory exemption to self-employed Amish and other religious persons, ${ }^{98}$ and subsequently afforded one for some taxpayers like Lee who had none at the time of the decision. ${ }^{99}$ But the Court was apparently uncomfortable in granting religious exemptions fron "neutral" taxation programs-an uneasiness made more obvious by subsequent decisions. ${ }^{100}$

In Jimmy Swaggart Ministries v. Board of Equalization, ${ }^{101}$ the Court again confronted a neutral tax that burdened a religion, although this time less directly in conflict with the faith's precepts. Jimmy Swaggart Ministries (JSM) contended that California's imposition of sales and use taxes upon the sale of its religious materials burdened free exercise imper-

Seleetive Service Act a compelling state interest). But see Mayer G. Freed \& Daniel D. Polsby, Race Religion and Public Policy: Bob Jones University v. United States, 1983 SuP. CT. Rev. 1, 20-30; Douglas Laycock, Tax Exemptions for Racially Discriminatory Religious Schools, 60 TEx. L. REv. 259 (1982) (criticizing the Court's reasoning in the Bob Jones case).

94. See O'Lone v. Estate of Shabazz, 482 U.S. 342, 353 (1987) (finding that in prison, security procedures that made Muslinu observances impossible were "reasonably related to legitimate penological objectives"); Goldnaan v. Weinberger 475 U.S. 503 (1986) (concluding that in the military, the need for uniformity to enforce respect and discipline overrides freedom to wear yarmulke).

95. 455 U.S. 252 (1982).

96. This belief, forbidding both the payment of the Social Security taxes and the receipt of benefits, is based on a literal interpretation of 1 Timothy 5:8: "'But if any provide not ... for those of his own house, he hath denied the faith and is worse than an infidel." Lee, 455 U.S. at 255 n.3.

97. See id. at 257-59.

98. See id. at 262 (Stevens, J., concurring).

99. See 26 U.S.C. $\$ 3121(\mathrm{w})$ (1984) (exempting "churches and qualified church-controlled organizations").

100. See, e.g., Hernandez v. Commissioner of Internal Revenue, 490 U.S. 680, 699-700 (1989) (conciuding even a substantial tax burden on Scientologists would be justified by "'broad public interest in maintaining a sound tax system,' free of 'myriad exceptions flowing fron a wide variety of religious beliefs." (quoting United States v. Lee, 455 U.S. 252, 260 (1982))).

101. 493 U.S. 378 (1990). 
missibly. The Court used the strict scrutiny test again, but this time held that the burden imposed by the tax-essentially, the reduction in revenue caused by the resulting increased prices of religious materials-was not "constitutionally significant." 102 This conclusion is plainly in tension with Sherbert. ${ }^{103}$ The Court made an unpersuasive distinction between the cases: It stated that since JSM's religious beliefs "do not forbid payment of the sales and use tax ... in no sense has the State "condition[ed] receipt of an important benefit upon conduct proscribed by a religious faith, or ... denie[d] such a benefit because of conduct mandated by religious belief."'104 To the Court, there was thus no "substantial pressure on an adherent to modify his behavior and to violate his beliefs." ${ }^{105}$ But neither did Adell Sherbert's beliefs require her to receive unemployment compensation if she lost her job. In neither situation did the state forbid the religiously mandated conduct of purchasing religious materials or declining to work on Saturday. Both claimants incurred costs imposed by the state as a result of their religiously motivated activity, and both sought special government accommodation in order to be relieved of those burdens.

But the most dramatic illustration of the neutrality theme (and also of the fourth theme, that of less protection for nonconforming religious groups) came in the Court's 1990 decision in Employment Division, Department of Human Resources v. Smith. ${ }^{106}$ Oregon denied unemployment compensation to two drug rehabilitation counselors who were fired from their jobs when it became known that, in violation of their agreement not to use drugs, they had ingested peyote, a controlled substance in Oregon, for sacramental purposes at a Native American Church ceremony. The basis for the state agency's decision that the drug counselors were ineligible for benefits was that they had been fired for work-related "misconduct." 107

Justice Scalia, writing for a majority of five, ${ }^{103}$ expressly appealed to the neutrality theme in holding the Sherbert-Yoder strict scrutiny test

102. Id. at 392.

103. See supra notes $24-26$ and accompanying text.

104. Jimmy Swaggart Ministries, 493 U.S. at 391-92 (citations omitted).

105. Id. at 392.

106. 494 U.S. 872. For a more detailed discussion of Smith, see Choper, supra note 8, at 670.

107. See Smith, 494 U.S. at 874 .

108. Although four members of the Court (Justices White, Brennan, Blackmun, and Marshall) in the Smith case have left the bench, it appears that a continuing majority would adhere to the Smith rule. Even on the reasonable assumptions that Justice Ginsburg (who replaced Justice White) would join the Smith minority's position, and that Justices Souter and Breyer (who replaced Justices Brennan and Blackmun) would share their predecessor's views (for a strong suggestion of this by Justice Souter, see Church of the Lukumi Babalu Aye, Inc. v. City of Hialeah, 508 U.S. 520, 559 (1993) (Souter, J., concurring)), there is good reason to believe that Justice Thomas (who replaced Justice Marshall) would side with the prevailing approach in Smith. But see Justice Thomas' dissent from denial of certiorari in Swanner v. Anchorage Equal Rights Commission, 513 U.S. 979 (1994) (Thomas, J., dissenting) (suggesting that state's refusal to grant religious exemption from ordinance prohibiting 
inapplicable to an "across-the-board criminal prohibition on a particular form of conduct" such as Oregon's listing of peyote as a "controlled substance." 109 To him, "[a]ny society" that required special exemptions for those objecting to generally applicable government regulations on religious grounds would be "courting anarchy" because of the practically unlimited range of regulations that could be subjected to religious challenges. ${ }^{110}$ Justice Scalia's language echoes the nineteenth-century reasoning of Reynolds, quoted above, ${ }^{111}$ in contrast to Chief Justice Burger's ringing words in Yoder that "[a] regulation neutral on its face may, in its application, nonetheless offend the constitutional requirement for government neutrality if it unduly burdens the free exercise of religion." 12

Smith poignantly illustrates theme four, the reduction in the level of Supreme Court protection for nonmainstream religions. The Court expressly conceded that its rejection of constitutionally required exemptions under the Free Exercise Clause would leave adherents of small religions in a more vulnerable position than adherents of "mainstream" faiths: "It may fairly be said that leaving accommodation to the political process will place at a relative disadvantage those religious practices that are not widely engaged in ...." 113 To justify the impact of its holding, the Court emphasized that "unavoidable consequence of democratic government must be preferred to a system in which each conscience is a law unto itself or in which judges weigh the social importance of all laws against the centrality of all religious beliefs." 114

It should be noted that the Smith majority observed that if states "made an exception to their drug laws for sacramental peyote use," it would be "permitted, or even ... desirable."115 This departure from a constitutional principle of absolute neutrality with respect to religion is in accord with the unanimous position of the Justices in Corporation of the Presiding Bishop of the Church of Jesus Christ of Latter-Day Saints $v$. Amos, ${ }^{116}$ which upheld a legislative exemption for religious organizations from a generally applicable statutory ban on religious discrimination in employment, reasoning that "it is a permissible legislative purpose to alleviate significant governmental interference with the ability of religious

landlords from refusing to rent because of prospective tenants' marital status violates Religious Freedom Restoration Act).

109. Smith, 494 U.S. at 884.

110. See id. at 888 .

111. See supra language quoted in text accompanying note 12 .

112. Wisconsin v. Yoder, 406 U.S. 205, 220 (1972) (citation omitted).

113. Snith, 494 U.S. at 890.

114. Id. For the view that this problem could be ameliorated by a limiting principle to narrow the range of claims that can be brought by religious objectors against generally applicable laws, see CHOPER, supra note 31, at 64-96; and Choper, supra note 8, at 679-80.

115. Smith, 494 U.S. at 890.

116. 483 U.S. 327 (1987). 
organizations to define and carry out their religious missions." 117 This qualification of its equality theme illustrates the present Court's deference to the majoritarian political process. ${ }^{18}$

There have been several significant developments for the free exercise of religion since the Court decided Smith. The first was the Court's unanimous reaffirmance of the umiversally accepted principle, directly supportive of the neutrality theme, that the Free Exercise Clause forbids government from singling out religion for adverse treatment. ${ }^{119}$ Second, and potentially of much greater importance, was the passage of the Religious Freedom Restoration Act of $1993,{ }^{120}$ in which Congress legislatively substituted the Court's pre-Smith approach for the neutrality principle that the Justices had announced in their ruling. Unlike a constitutionally guaranteed right, the Act's protections were subject to elimination or substantial modification at any time by a simple exercise of legislative will. Nevertheless, the Act erected a new mantle of security for the welfare of religious minorities, once again entrusting the federal judiciary with substantial guardianship responsibilities. In 1997, however, the Supreme Court ruled that the Act was unconstitutional as beyond Congress's delegated power to enforce the free exercise of religion. ${ }^{121}$ The Court reasoned that Congress's power to remedy violations of the Fourteenth Amendment does not include the power to determine what constitutes a violation of equal protection or due process because it is the function of the Court, not Congress, to define the substance of constitutional rights. ${ }^{122}$

117. Id. at 335.

118. As earlier indicated, see supra text accompanying notes 76-78, I do not believe that the Establishment Clause should be interpreted to forbid legislative accommodations for religion as long as the exemptions pose no meaningful threat to religious liberty. For further discussion, see CHOPER, supra note 31 , at $119-33$.

119. See Church of the Lukumi Babalu Aye, Inc. v. City of Hialeah, 508 U.S. 520 (1993) (invalidating an ordinance banning ritual animal sacrifice, while allowing most other kinds of animal killings, because it targeted the religious practice of the Santeria faith). The Court's standard for reviewing discrimination against religion was not absolute: " $[\mathrm{I}] \mathrm{t}$ is invalid unless it is justified by a compelling interest and is narrowly tailored to advance that interest." Id. at 533. But it is extremely unlikely that any such deliberate disadvantage of one or all religions could survive this strict scrutiny and be upheld.

The counterpart to the Free Exercise Clause's virtually total prohibition of state discrimination against one or all religions is "a principle at the heart of the Establishment Clause, that government should not prefer one religion to another, or religion to irreligion." Board of Educ. of Kiryas Joel Village Sch. Dist. v. Grumet, 512 U.S. 687, 703 (1994) (emphasis added) (finding a violation of the Establishment Clause in a state-created special school district for one religious group).

120. 42 U.S.C. $\$ 2000 \mathrm{bb}$ (1994).

121. See City of Boerne v. Flores, 521 U.S. 507 (1997).

122. See id. 


\section{B. Separation of Church and State}

\section{Government Financial Assistance to Religious Institutions}

Until recently, this area had remained the principal arena in which the Court continued to use the Lemon test, especially its "purpose" and "effect" prongs. A rough but generally accurate statement of the rule that had governed this area, produced largely by the votes of Justice Lewis F. Powell, is that it was permissible for government aid to go to children or their parents who make the private choice to send their children to parochial schools, whereas it was impermissible for the aid to go directly to the parochial schools themselves. ${ }^{123}$

The Court's later rationales tended to invoke the Lemon test while emphasizing the theme of neutrality. An early illustration of this approach in 1986, Witters v. Department of Services for the Blind, ${ }^{124}$ involved a Washington program providing vocational rehabilitation assistance in the form of a voucher (although it was not called that) to the visually impaired that could be used to defray educational costs. The applicant in this case sought to use the aid at a Bible college where he was preparing for a career as a pastor, missionary, or youth director. ${ }^{125}$ The Washington Supreme Court applied the Lemon test and found an impermissible effect under the Establishınent Clause: "The provision of financial assistance by the state to enable someone to become a pastor, missionary, or church youth director clearly has the primary effect of advancing religion."126

The U.S. Supreme Court reversed, finding no Establishment Clause violation. Justice Thurgood Marshall, ordinarily a quite strict separationist, wrote the unanimous opinion. Because the aid went to the student, not to the school, and thus any benefit to the school came as the result of the private choice of the individual recipient, not the government, Justice Marshall found no "primary effect" of advancing religion. ${ }^{127}$ Also relying upon the type of empirical approach that the Court had only recently refused to follow in order to invalidate an aid program, ${ }^{128}$ he emphasized that no "significant portion" of the plan's resources would "end up flowing to religious education." 129

123. See Jesse H. Choper, The Establishment Clause and Aid to Parochial Schools-An Update, 75 CALIF. L. Rev. 5 , 13 (1987).

124. 474 U.S. 481 (1986).

125. See id. at 483 .

126. Witters v. Commission for the Blind, 689 P.2d 53, 56 (Wash. 1984), rev'd sub nom, Witters v. Dep't of Servs. for the Blind, 474 U.S. 471 (1986).

127. Witters, 474 U.S. at 486-89. A majority of the Court had rejected that distinction a decade earlier, in Committee for Public Education v. Nyquist, 413 U.S. 756, 781-83 (1973), as had Justice Marshall himself in a persuasive dissent that relied on Nyquist just three years before, in Mueller $v$. Allen, 463 U.S. 388, 407-08 (1983) (Marshall, J., dissenting) (upholding tax deductions for educational purposes in all schools, including religious schools).

128. See id. at 401 .

129. Witters, 474 U.S. at 488. 
More importantly, the concurring opinions in Witters appeared to promise that a majority of the Court-the same Justices who comprised the majority in Mueller v. Allen ${ }^{130}$ - would find a broad state program providing parents of all elementary or secondary school children with vouchers to be constitutional. Citing Mueller, Justice Powell (joined by Chief Justice Warren Burger and Justice Rehnquist) emphasized that "state programs that are wholly neutral in offering educational assistance to a class defined without reference to religion do not violate the second part of the Lemon $v$. Kurtzman test, because any aid to religion results from the private choices of individual beneficiaries." 131 Since Justices White and O'Connor wrote separate opinions agreeing with Justice Powell with respect to the significance of Mueller, ${ }^{132}$ it appeared to some that the Court was prepared to cross the line it had drawn in the Lemon test.

Although the Witters rationale might seem to apply to a conventional voucher system for elementary and secondary schools, that case involved higher education and the Court has drawn a sharp distinction between these different types of recipients of public aid. ${ }^{133}$ Moreover, three recent cases indicate that while a majority of the Court may broadly support neutral programs that financially assist religious institutions, they may not be completely ready to allow the neutrality principle to trump another long held precept of the Religion Clauses: Government may not fund religious activities. In particular, I believe that the more recent opinions of one of the five members of the Witters majority, Justice O'Connor, caution against counting on her support for any broad program providing aid to parochial schools.

The first of these cases is Zobrest v. Catalina Foothills School District, ${ }^{134}$ involving the state's payment of a sign-language interpreter for a deaf student in a Catholic high school as part of a general program of aid to children with disabilities. The Court of Appeals for the Ninth Circuit had relied on the Lemon test in finding this practice unconstitutional, ${ }^{135}$ but the Supreme Court upheld it. Ignoring Lemon once again, the Court instead looked to Witters for the principle of theme one: "[G]overnment programs that neutrally provide benefits to a broad class of citizens defined without reference to religion are not readily subject to an Establishment Clause challenge just because sectarian institutions may also receive an attenuated

\footnotetext{
130. 463 U.S. 388 (1983).

131. Witters, 474 U.S. at 490-91 (Powell, J., concurring) (citation omitted).

132. See id. at 490 (White, J., concurring); id. at 493 (O'Connor, J., concurring).

133. Compare Lemon v. Kurtzman, 403 U.S. 602 (1971) (discussed supra at text accompanying notes 61-64), with Tilton v. Richardson, 403 U.S. 672 (1971) (upholding government grants or tax benefits for construction of buildings to be used exclusively for secular education at church-related colleges). See also Roemer v. Board of Pub. Works, 426 U.S. 736 (1976); Hunt v. McNair, 413 U.S. 734 (1973).

134. 509 U.S. 1 (1993).

135. See Zobrest v. Catalina Foothills Sch. Dist., 963 F.2d 1190 (9th Cir. 1992).
} 
financial benefit." ${ }^{136}$ Although Justice O'Connor's dissent from the Court's decision was not on the merits of the Establishment Clause issue, it suggested that she might be reluctant to follow to its full distance the course of reasoning in the Mueller and Witters opinions that she had joined. ${ }^{137}$

Since the program in Zobrest involved payment of state funds to a state employed sign-language interpreter, one could reasonably argue that it does not establish any precedent for a direct government transfer to a religious institution. ${ }^{138}$ This appeared to be the situation in Rosenberger $v$. Rector \& Visitors of University of Virginia, ${ }^{139}$ which raised the question of whether the university could use inoney from its Student Activities Fund to pay the printing costs of the student newspaper "Wide Awake," which "offers a Christian perspective on both personal and community issues, especially those relevant to college students at the University of Virginia," 140 as part of a general program to fund various communications by student groups. The Court found no violation of the Establishment Clause, grounding its analysis firmly in theme one: "[T]he governmental program here is neutral toward religion." "141 There are several reasons, however, for doubting that Rosenberger means, as has been contended, that all forms of financial assistance to religion are now permissible, even if the money is spent for core religious activities rather than for secular purposes, as long as the aid is part of a neutral general program. ${ }^{142}$

The majority opinion, written by Justice Kennedy and joined by Chief Justice Rehnquist and Justices O'Connor, Scalia, and Thomas, placed two important limitations on the scope of the Court's ruling. First, Justice Kennedy emphasized that the university was not transferring funds directly to the religious student organization that published the newspaper. Rather, the check was drawn to the printer of the newspaper with which the religious organization had contracted to produce it. ${ }^{143}$ While this may not be a very persuasive distinction, the majority's use of this formalistic reasoning plainly indicates its discomfort in permitting the government to fund rehigious activities. ${ }^{144}$ Second, Justice Kennedy pointed out that the case did

136. Zobrest, 509 U.S. at 8 . The Court noted as well that this program did not involve "direct grants of government aid" that "relieved sectarian schools of costs they otherwise would have borne in educating their students." Id. at 12.

137. See supra discussion accompanying notes 126-32.

138. See supra notes $127 \& 136$, pointing to language in botl Witters and Zobrest emphasizing that no public funds were granted directly by government to recipient schools.

139. 515 U.S. 819 (1995).

140. Id. at 826 (citation omitted).

141. Id. at 840 .

142. See, e.g., Michael Stokes Paulsen, A Funny Thing Happened on the Way to the Limited Public Forum: Unconstitutional Conditions on "Equal Access" For Religious Speakers and Groups, 29 U.C. DAvis L. REv. 653 (1996).

143. See Rosenberger, 515 U.S. at 844.

144. See id. at 847 (O'Connor, J., concurring) ("This case lies at the intersection of the principle of government neutrality and the prohibition on state funding of religious activities."). 
not involve general support for the efforts of a religious institution. Rather, it was confined to financial aid for newspapers. ${ }^{145}$ If the University of Virginia were barred from funding religious newspapers, the Court reasoned, some university administrator would have to review all the student publications and determine whether they were religious or not. This raises the specter of classic censorship and its consequent chilling effect on the freedoms of speech and press. Justice Kennedy's second arguinent is plainly unore appealing than his first distinction. More important for our purposes, however, is the fact that this point underlines the narrowness of the Court's decision, restricting its rationale to government funding of newspapers published by religious organizations and nothing else.

The most critical limiting distinction, however, came in a concurrence written by Justice O'Connor. ${ }^{146}$ (That it is a separate opinion does not dimimish its importance because Justice O'Connor is one of the five members of the Conrt that made up the majority.) She stressed that the money for the University of Virginia's Student Activities Fund came from student fees, not froin the University's general account. Justice O'Connor opined that it may be possible that any students who have ideological objections to the way the inoney is spent have a First Amendment right to opt out and obtain a refund. ${ }^{147}$ That is a far-reaching limitation. Taxpayers have no constitutional right to opt out if the way government spends compulsorily raised tax funds conflicts with their political views. Thus, she would distinguish virtually all other government expenditure programs-among thein, voucher prograins that include religious schools-from the one in Rosenberger.

The most recent case in this area, Agostini v. Felton, ${ }^{148}$ further raises the possibility that while a majority of the Court, at least as presently constituted, embraces the neutrality principle, it might still strike down a neutral voucher plan that includes religious schools. Agostini overruled the Court's 1985 decision in Aguilar v. Felton, ${ }^{149}$ which involved the use of funds under Title I of the Elementary and Secondary Education Act of $1965^{150}$ for parochial schools. In Agostini, the New York City Board of Education sought to supply Title I services on private school premises

145. See id. at 840 .

146. See id. at 846 (O'Connor, J., concurring).

147. See id. at 851. In support of this possible right, Justice O'Connor cited Keller v. State Bar, 496 U.S. 1 (1990) (involving compulsory state bar dues), and Abood v. Detroit Board of Education, 431 U.S. 209 (1977) (concerning mandatory "service chargcs" to union as condition of employment as public school teacher).

148. 521 U.S. 203 (1997).

149. 473 U.S. 402 (1985).

150. The Elementary and Secondary Education Act of 1965, Pub. L. No. 89-10, 79 Stat. 27 (codified as amended in scattered sections of 20 U.S.C.). Title I provides funds to "local education agencies" for "remedial education, guidance, and job counseling to eligible students," who include those in low income areas who are (or at risk of) failing. Agostini, 521 U.S. at 209. 
during school hours. The Board attempted to avoid Establishment Clause problems by providing that "only public employees could serve as Title I instructors and counselors," 151 and by monitoring instructors to be sure that they did not stray from their secular purpose. ${ }^{152}$

Justice Brennan had written for the Aguilar majority of five that this plan ran afoul of the third prong of the Lemon test, relying on the insoluble dilemma that the Lemon test had posed for state aid programs that included parochial schools. Beginning with the critical premise that the mission of church-related elementary and secondary schools is to teach religion and that all subjects carry the potential of being permeated with sectarian views, the Court found that the very monitoring that was supposed to prevent the program from being used to inculcate religion (and thus violate Lemon's second prong) was so "pervasive" as to "infringe[] precisely those Establishment Clause values at the root of the prohibition of excessive entanglement." ${ }^{153}$ In addition, the New York program shared key problems with a Michigan plan struck down the same day in Aguilar's companion case. ${ }^{154}$ Paying public employees to teach supplemental courses at religious schools violated the second prong of the Lemon test-it had the " primary or principal' effect of advancing religion." upon three key assumptions: (1) public employees teaching in parochial schools may be influenced by their surroundings to "subtly or overtly indoctrinate students in particular religious tenets at public expense"; (2) they inherently create a "symbolic union of church and state"; and (3) public provision of such services impermissibly "subsidize[s] the religious functions of the parochial schools."156 Of course, these factors would not only preclude the use of publicly-paid teachers in parochial schools, but also would, a fortiori, make unconstitutional any school voucher program, however neutrally applied.

The parties in Aguilar returned thirteen years later armed with the decisions in Witters and Zobrest, and argued that these assumptions no longer represented the opinion of the Court. Five Justices agreed. The majority opinion, written by Justice O'Connor, quite cautiously limited its holding to the particular facts of the case. Justice O'Connor first stressed that, as in Zobrest, "Title I services are by law supplemental to the regular curricula ... [and] do not, therefore, 'relieve sectarian schools of costs they

151. Id. at 211 .

152. Most notably, the school board included a provision that "a publicly employed field supervisor was to attempt to make at least one unannounced visit to each teacher's classroom every month." Id. at 212 (citations omitted).

153. Aguilar, 473 U.S. at 413.

154. See School Dist. of Grand Rapids v. Bail, 473 U.S. 373 (1985). For a discussion of this case, see infra notes 161-64 and accompanying text.

155. Id. at 397 .

156. Id. 
otherwise would have borne in educating their students." "157 Next, she pointed out that "[n]o Title I funds ever reach the coffers of religious schools." 158 Finally, Title I instructors were assigned "without regard to [their] religious affiliation ... or the wishes of the private school," and a "large majority of Title I teachers worked in nonpublic schools with religious affiliations different from their own."159 Thus, although Agostini certainly demonstrates that the Court is no longer as strictly separationist as it was fifteen years ago, it cannot be characterized as a green light for school voucher programs. Justice O'Connor's opinion merely removes the presumption that "the placement of public employees on parochial school grounds inevitably results in the impermissible effect of state-supported indoctrination or constitutes a symbolic union between government and religion." 160

I believe her careful opinion in Agostini shows that Justice O'Connor-and since she holds its deciding vote, the current Court-has not generally endorsed public aid to parochial schools. Her opinion in School District of Grand Rapids v. Ball ${ }^{161}$ is particularly telling. There, after disagreeing with the majority's assessment of Michigan's "Shared Time" program, ${ }^{162}$ she concurred that the "Community Education" program, which offered general academic and hobby courses to children and adults at nonpublic schools, ${ }^{163}$ violated the Establishment Clause. She stated in no uncertain terms that "[w]hen full-time parochial school teachers receive public funds to teach secular courses to their parochial school students under parochial school supervision, I agree that the program has the perceived and actual effect of advancing the religious aims of the church-related schools."164 When combined with her careful concurrence in Rosenberger, and her opinion for the Court in Agostini, this statement suggests that Justice O'Connor's allegiance to the theme of neutrality is by no means absolute.

While the full reach of the neutrality principle remains unsettled, there is no question about its greatly increased influence. Rosenberger's result is telling, for neither Justice Kennedy's opinion for the Court nor Justice O'Connor's concurrence employed the analysis of the Lemon test in any way. Though the test again played a role in Agostini, the majority

157. Agostini, 521 U.S. at 228 (quoting Zobrest v. Catalina Foothills Sch. Dist., 509 U.S. 1, 12 (1993)) (citations omitted).

158. Id. at 228 .

159. Id. at 211 .

160. Id. at 223 (emphasis added).

161. 473 U.S. 373 (1985).

162. "Shared Time" was quite similar to the New York City program at issue in Aguilar and Agostini; it used public funds to provide "remedial" and "enrichment" classes to students attending nonpublic schools. See Ball, 473 U.S. at 375.

163. See id. at 376-77.

164. Id. at $399-400$. 
opinion referred approvingly to the neutrality principle ${ }^{165}$ and appears to redefine the "effect" prong of the Lemon test. It announced "three primary criteria ... to evaluate whether government aid has the effect of advancing religion": 166 (1) whether the aid results in governmental indoctrination; (2) whether the aid recipients are defined by reference to religion; and (3) whether it creates an "'excessive' entanglement."167 Finally, the latest cases involving government financial assistance illustrate theme three, the Court's greater accommodation of "mainstream" religions, because it is mainly these kinds of religious organizations that are large enough to engage in activities such as operating parochial schools. ${ }^{168}$

My own views on the subject of aid to parochial schools give content to my overall approach to the Religion Clauses. I believe that, both historically and contemporarily, a meaningful danger to religious liberty is posed when compulsorily raised tax funds are expended for religious purposes. It violates my religious liberty to have my tax-raised funds spent for even my own religion (because they are not voluntarily spent), and it compounds the violation if they are spent to support some religion with which I am not affiliated or with whose precepts I disagree. Even so, most aid to parochial schools would probably be upheld under my approach. There is a nonreligious purpose and effect as long as the amount of the government expenditure does not exceed the value of secular educational services provided by the parochial schools. To put it another way, as long as the government receives full secular value for its money, there is no expenditure of tax funds for religious purposes and thus no meaningful danger to religious liberty. ${ }^{169}$

\section{Government Acknowledgment of Religion}

This area is composed entirely of about six decisions, all decided within the past fifteen years. It contains several influential discussions of what the appropriate constitutional standard should be for adjudicating Establishment Clause challenges. In four cases, the Court has upheld government acknowledgments of religion. First, in Marsh v. Chambers, ${ }^{170}$ the Court sustained the Nebraska legislature's practice of opening each session with a prayer by a government-paid chaplain. Second, in Lynch $v$.

165. See Agostini, 521 U.S. at 224-25.

166. Id. at 206 .

167. Id. at 233-34.

168. See also Bowen v. Kendrick, 487 U.S. 589 (1988) (rejecting a facial challenge to a federal statute providing funding for educational programs to combat adolescent sexuality and pregnancy). Chief Justice Rehnquist's opinion for the Court found that the statute's express authorization of participation by religious organizations along with various other types of community organizations maintained "'a course of neutrality among religions, and between religion and non-religion." Id. at 607 (quoting Ball, 473 U.S. at 382).

169. See supra text accompanying notes 76-77.

170. 463 U.S. 783 (1983). 
Donnelly, ${ }^{171}$ the Court upheld the city of Pawtucket's inclusion of a nativity scene as part of a larger Christmas display in a city park. Third, in County of Allegheny v. American Civil Liberties Union, ${ }^{172}$ the Court affirmed the display of a menorah along with a Christmas tree near the entrance to an office building owned by the city of Pittsburgh and Allegheny County. Finally, in Capitol Square Review and Advisory Board v. Pinette, ${ }^{173}$ the Court overruled the state's refusal to permit the Ku Klux Klan to erect a Latin Cross in the plaza surrounding the Ohio statehouse.

Each of these decisions illustrates the third theme: the Court's tendency to be less separationist and more accommodating of mainstream religions. The Court's rationale in these four cases varied considerably, from a focus on history and original intent in $\mathrm{Marsh}^{174}$ to finding a secular purpose for the display in Lynch, ${ }^{175}$ to reasoning that the display of the menorah did not constitute an endorsement of Judaism in Allegheny, ${ }^{176}$ to emphasizing the state's neutrality in Pinette because the plaza had been opened generally to the public with prior displays in the forum by various private groups. ${ }^{177}$ In the main, however, the Court's actions make clear that there are various types of public government acknowledgments of religion that do not violate the Establishment Clause-that is, no strict separation between government and religion is required.

Under my own approach, "accommodations" for religious interests should not be held to violate the Establishment Clause when no meaningful threat to individual religious freedom can be said to exist. It should be of no consequence that such accommodations may mean that the goverument is acting with a religious purpose, or that they may be perceived by reasonable observers as constituting symbolic endorsements of religion. That someone may take offense at government acknowledgment of religion, or that strife may occur along religious lines if the government erects (or refrains from erecting) a holiday display that includes religious symbols, should not be determinative.

Official recognition of religion in some circumstances can be successfully challenged. Lee $v$. Weisman, ${ }^{178}$ invalidating the practice of public school officials inviting members of the clergy to offer invocation and benediction prayers at graduation ceremonies, illustrates one of the Court's more accommodationist Justices finding an Establishment Clause violation in this context. The majority opinion, written by Justice Kennedy, reasoned

171. 465 U.S. 668 (1984).

172. 492 U.S. $573(1989)$.

173. 515 U.S. 753 (1995).

174. See Marsh, 463 U.S. at 786-92.

175. See Lynch, 465 U.S. at 680-81.

176. See Allegheny, 492 U.S. at 613-21.

177. See Pinette, 515 U.S. at 764-70.

178. 505 U.S. 577 (1992). 
that the "government involvement with religious activity in this case is pervasive, to the point of creating a state-sponsored and state-directed religious exercise in a public school" where "subtle coercive pressures exist and where the student had no real alternative which would have allowed her to avoid the fact or appearance of participation."179 The four members of the Court who joined Justice Kennedy's opinion-Justices Blackmun, Stevens, O'Connor, and Souter-also wrote separately to underline their view that official "endorsement" of religion transgresses the Establishment Clause even though "coercion" may not be present. ${ }^{180}$ As we shall see again shortly, both the endorsement and coercion approaches often, but not always, produce the same outcome. Thus, although there was agreement in Allegheny County that neither test was abridged by the menorah-Christmas tree display, the endorsement proponents led the Court to hold that the display of a crèche in the Allegheny County courthousestanding alone, and not part of a larger Christmas celebration-violated the separation of church and state. Four members of the Court, led by Justice Kennedy, dissented and would have upheld it under their coercion test. ${ }^{181}$

At this writing, the Court has not formally rejected the Lemon test in favor of the endorsement approach. But the opinions of the Justices in Pinette make clear that this has in fact occurred. Four members of the present Court-Justice Scalia, joined by Chief Justice Rehnquist and Justices Kennedy and Thomas-contended that since the Capitol Square Board's policy of permitting various displays on the state house plaza was neutral, there could be no Establishment Clause objection even though the government policy may have resulted in substantial benefit to religion, and even though some people may infer government endorsement despite its neutral stance. ${ }^{182}$

More importantly, however, the other three members of the sevenjustice majority-Justices O'Connor, Breyer, and Souter-produced two separate concurrences. They maintained that there is an Establishment Clause violation even though a government program is neutral if, under Justice O'Connor's approach, it can be reasonably perceived as an "endorsement" of religion. Simce the two dissenting members of the Court, Justices Stevens and Ginsburg, agreed with Justice O'Connor that an endorsement of religion by government, even as part of a neutral program, is a violation of the Establishment Clause, ${ }^{183}$ the Pinette case was highly

179. Id. at 587-88.

180. See id. at 606 (Blackmun, J., concurring); id. at 619 (Souter, J., concurring).

181. See Allegheny, 492 U.S. at 598-603, 656-68.

182. See Pinette, 515 U.S. at 762-69.

183. Justice Stevens has directly subscribed to Justice O'Connor's "endorsement" approach for Establishment Clause interpretation on a number of occasions. See, e.g., Capitol Square Review \& Advisory Bd. v. Pinette, 515 U.S. 753, 797-800 (1995) (Stevens, J., dissenting); County of Allegheny v. ACLU, 492 U.S. 573, 650 (1989) (Stevens, J., concurring in part and dissenting in part); Wallace v. 
significant for doctrinal purposes. Although the accomodationists won the battle in this particular dispute, ${ }^{184}$ they lost the war of determining a replacement for the Lemon test. The more separationist position of endorsement now has garnered five votes, and that would seem to be the prevailing test for alleged violations of the Establishment Clause, at least until the next Justice comes along. Nonetheless, the potential for a shift in position as the Court's composition changes makes it particularly important to understand the implications of the "coercion" and "neutrality" approaches as well as the endorsement test.

\section{Religion in Public Schools}

The most important recent decision in this final area of church-state adjudication is Board of Education v. Mergens, ${ }^{185}$ which strongly illustrates the themes of neutrality and accommodation of mainstream religions. Mergens involved an Establishment Clause review of the Equal Access Act, ${ }^{186}$ in which Congress prohibited public secondary schools that receive federal funds and that maintain a "limited open forum," which exists whenever the school permits "noncurriculum related student groups to meet on school premises during noninstructional time," 187 from denying "equal access" on the basis of the content of the speech at such meetings. ${ }^{188}$ The case was brought by public high school students whose request for permission to form a Christian club at the school was denied. The students sought to meet on the same terms as other student groups, except that the proposed club would not have a faculty sponsor. Membership would have been voluntary and open to all students regardless of religious affiliation. ${ }^{189}$ Although the.Court voted eight to one to uphold the constitutionality of the Equal Access Act, there was no majority opinion on the issue. The principal prevailing opinions of Justices O'Connor and Kennedy both underline

Jaffree, 472 U.S. 38 (1985) (opinion for the Court by Stevens, J.). Although Justice Ginsburg's adherence to the "endorsement" principle has been less explicit, see id. at 817-18 (Ginsburg, J., dissenting) (stating that it was unclear that Ohio "did not endorse" the cross), it would appear to be closer to the separationist rationale that she favors than any other approacb that is capable of attracting a majority.

184. The Court upheld the KKK's erection of the Latin Cross because concurring Justices O'Connor, Souter, and Breyer, who were necessary to make a majority, found that a disclaimer sign could clarify that the KKK's cross did not have the "sponsorship or endorsement" of government. See Pinette, 515 U.S. at 776. (Justice Ginsburg dissented on the ground tbat "[n]o plainly visible sign informed the public that the cross belonged to the Klan and that Ohio's govcrnment did not endorse the display's message." Id. at 817.) It is therefore clear that a disclaimer sign was needed to avoid a reasonable perception of government endorsement, regardless of the ncutrality of the state's activity, program, or policy.

185. 496 U.S. 226 (1990).

186. 20 U.S.C. $\$ \S 4071-4074$ (1994).

187. Id. \$ 4071(b).

188. See id. \$4071(a).

189. See Mergens, 496 U.S. at 232. 
the first theme of neutrality and the third theme of accommodation. ${ }^{190}$ Both Justices also amplified their competing Establishment Clause approaches.

The school argued that the Act would require it "effectively [to] incorporate religious activities into the school's official program," thus "endors[ing] participation in the religious club, and provid[ing] the club with an official platform to proselytize other students." 191 In response, Justice O'Connor distinguished between "government speech endorsing religion, which the Establishment Clause forbids, and private speech endorsing religion, which the Free Speech and Free Exercise Clauses protect."192 Based on that distinction, Justice O'Connor found no governmental "endorsement" of religion because "secondary scliool students are mature enough and are likely to understand that a school does not endorse or support student speech that it merely permits on a nondiscriminatory basis."193

In accordance with his principle "that the government cannot coerce any student to participate in a religious activity,"194 Justice Kennedy found that the Act

does not authorize school authorities to require, or even to encourage, students to become members of a religious club or to attend the club's meetings; the meetings take place while school is not im session; and the Act does not compel any school employee to participate im, or to attend, a club's meetings or activities. ${ }^{195}$

Justice Kennedy acknowledged that the coercion inquiry "must be undertaken with sensitivity" to its more subtle forms but found no indication of any indirect pressure to participate in the club. ${ }^{196}$

Justice Kennedy criticized Justice O'Connor's endorsement test, however, on the ground that "[t]he word endorsement has insufficient content to be dispositive." 197 He illustrated this point in Mergens by statimg that he would have reached the opposite result under the endorsement test:

190. See id. at 247 (O’ Connor, J.); id. at 258 (Kennedy, J., concurring).

191. Id. at 247-48.

192. Id. at 250.

193. Id.

194. Id. at 260 (citations to Justice Kennedy's separate opinions in Allegheny and Lynch v. Donnelly omitted).

195. Id. at 261 (citations omitted).

196. Id. Justice Scalia joined Justice Kennedy's concurrence in Mergens but vigorously dissented from Justice Kennedy's opinion for the Court in Lee v. Weisman, 505 U.S. 577 (1992), which had found "subtle coercive pressures" at the graduation ceremonies. See supra text accompanying note 179 . Joined by Chief Justice Rehnquist and Justices White and Thomas, Justice Scalia characterized the basis for the majority's analysis as "ersatz 'peer pressure' psycho-coercion." Lee, 505 U.S, at 641 (Scalia, J., dissenting). In the dissent's view, "[t]he coercion that was a hallmark of historical establishments of religion was coercion of religious orthodoxy and of financial support by force of law and threat of penalty." Id. at 640 .

197. Mergens, 409 U.S. at 261. For scholarly commentary regarding difficulties with the endorsement test, see CHOPER, supra note 31, at 27-34; Steven D. Smith, Symbols, Perceptions, and 
I should think it inevitable that a public high school "endorses" a religious club, in a common-sense use of the term, if the club happens to be one of many activities that the school permits students to choose in order to further the development of their intellect and character in an extracurricular setting. ${ }^{198}$

The extent to which the movement towards neutrality or equality of access that is evidenced in Mergens will affect other religion-in-the-publicschools practices remains to be seen. The present Court's acceptance of Justice O'Connor's endorsement test, however, promises to have special significance as the Court deals with these issues in the future. For example, the constitutionality of religious instruction on public school premises during "released time," which has been invalid since McCollum v. Board of Education, ${ }^{199}$ might hinge for Justice O'Connor (and for Justice Kennedy, and those who subscribe to his position) upon the breadth of the range of alternatives offered to students under such a program. ${ }^{200}$ Regarding prayer or Bible reading in public schools, ${ }^{201}$ it is even possible to speculate that the endorsement approach may prove to be less separationist than Justice Kennedy's coercion approach. For example, if a school were to institute a program of opening each school day with a reading 'from a wide variety of materials-say, some version of the Bible on Monday, an historically famous speech on Tuesday, a selection from great literature on Wednesday, and so on-that might be enough for Justice O'Connor to find no "endorsement." By contrast, the fact that a program draws from a variety of sources should theoretically make no difference under Justice Kennedy's approach. Although Bible-reading would take place only on some days, "coercion" to participate in a religious exercise would then occur. ${ }^{202}$ On the other hand, while the posting of the Ten Commandments in a public classroom would be a much closer question under Justice

Doctrinal Illusions: Establishment Neutrality and the "No Endorsement" Test, 86 MicH. L. REv. 266, 283, 301-03, 310-12 (1987); The Supreme Court, I988 Term-Leading Cases, 103 HARv. L. REv. 137, 234 (1989).

198. Mergens, 409 U.S. at 261.

199. 333 U.S. 203 (1948); see supra text accompanying note 44.

200. For discussion of the constitutionality of on-site programs allowing instruction in religion in addition to other subjects after Widmar v. Vincent, 454 U.S. 263 (1981), and Mergens, see Douglas Laycock, Equal Access and Moments of Silence: The Equal Status of Religious Speech by Private Speakers, 81 Nw. U. L. REV. 1, 33-35 (1986).

201. See, e.g., Abington Sch. Dist. v. Schempp, 374 U.S. 203 (1963) (Bible reading and recitation of Lord's Prayer); Engel v. Vitale, 370 U.S. 421 (1962) (nondenominational theistic prayer).

202. As Justice Kennedy wrote for a majority of the Court in Lee v. Weisman, "prayer exercises in public schools carry a particular risk of indirect coercion... Research in psychology supports the common assumption that adolescents are often susceptible to pressure from their peers towards conformity, and that the influence is strongest in matters of social convention." 505 U.S. at 592-93. Compare the view of the dissenters in Lee, see supra note 196, casting some doubt on their adherence to the Court's "school prayer" cases, cited supra in note 201. See also Lee, 505 U.S. at 643 ("[W]hatever the merit of those cases, they do not support, mueh less compel, the Court's psychojourney."). 
Kennedy's coercion approach than it was for the Court nearly two decades ago, ${ }^{203}$ Justice O'Connor would probably find this and such other practices as the teaching of "creation science," of silence, to constitute endorsement. ${ }^{205}$ By contrast, it is doubtful that Justice Kennedy would find them to be coercive.

\section{III}

\section{AN UNCERTAIN FUTURE}

The Supreme Court is presently split closely on almost all important issues of freedom of religion and separation of church and state. Justice O'Connor, who often determines the balance, has expressed the view that resolution of difficult issues in this area "depends on the hard task of judging-sifting through the details .... Such judgment requires courts to draw lines, sometimes quite fine, based on the particular facts of each case. ${ }^{206}$ As a consequence of these realities, the current development of the law provides more themes than categorical principles, with little doctrinal stability. The next President who initiates a modest change in the Court's composition has the potential to generate substantial doctrinal shifts. Only time will tell whether or not they will in fact occur.

One hundred years ago, the First Amendment's Religion Clauses meant something entirely different than what they mean today. If, a century from now, readers yet unborn discover this Essay (presumably in some dustless digital archive), I can only predict that they will marvel, as I do now, at the doctrinal distance we have traveled.

203. See Stone v. Graham, 449 U.S. 39 (1980) (finding the practice a violation of the Establishment Clause).

204. See Edwards v. Aguillard, 482 U.S. 578, 585 (1987) (invalidating a law requiring that the scientific method supporting the theory of creation be taught whenever evolution was taught because the statute had "no clear secular purpose").

205. Justice O'Connor found endorsement in Alabama's program in Wallace v. Jaffree, 472 U.S. 38, 78-79 (1985) (holding that a law setting aside a time of silence in public schools for "meditation or voluntary prayer" violates the Establishment Clause when its sole purpose, as evidenced by its text and legislative history, is to endorse a rehigious exercise, and thus it has no secular purpose). She also found endorsement in Louisiana's requirement in Aguillard, 482 U.S. at 593.

206. Rosenberger v. Rector \& Visitors of Univ. of Va., 515 U.S. 819, 847 (1995) (O'Connor, J., concurring). 
